\title{
Correction to: Small-Scale Dynamic Aurora
}

\author{
Ryuho Kataoka ${ }^{1,2}$ (D) Christopher C. Chaston ${ }^{3}$. David Knudsen ${ }^{4} \cdot$ Kristina A. Lynch $^{5}$. \\ Robert L. Lysak ${ }^{6} \cdot$ Yan Song ${ }^{6} \cdot$ Robert Rankin $^{7} \cdot$ Kiyoka Murase $^{2} \cdot$ Takeshi Sakanoi $^{8}$. \\ Joshua Semeter ${ }^{9} \cdot$ Tomo-Hiko Watanabe $^{10} \cdot$ Daniel Whiter $^{7}$
}

Published online: 26 April 2021

(c) The Author(s) 2021

\section{Correction to: Space Sci Rev (2021) 217:17 \\ https://doi.org/10.1007/s11214-021-00796-w}

The article, Small-Scale Dynamic Aurora, written by Kataoka, R., Chaston, C., Knudsen, D. et al., was originally published Online First without Open Access. After publication in volume 217, issue 1, page 17 the author decided to opt for Open Choice and to make the article an Open Access publication. Therefore, the copyright of the article has been changed to (C) The Author(s) 2021 and the article is forthwith distributed under the terms of the Creative Commons Attribution 4.0 International License, which permits use, sharing, adaptation, distribution and reproduction in any medium or format, as long as you give appropriate credit to the original author(s) and the source, provide a link to the Creative Commons licence, and indicate if changes were made. The images or other third party material in this article are included in the article's Creative Commons licence, unless indicated otherwise in a credit line to the material. If material is not included in the article's Creative Commons licence and your intended use is not permitted by statutory regulation or exceeds the permitted use, you will need to obtain permission directly from the copyright holder. To view a copy of this licence, visit http://creativecommons.org/licenses/by/4.0.

Open Access This article is licensed under a Creative Commons Attribution 4.0 International License, which permits use, sharing, adaptation, distribution and reproduction in any medium or format, as long as you give appropriate credit to the original author(s) and the source, provide a link to the Creative Commons licence, and indicate if changes were made. The images or other third party material in this article are included in the article's Creative Commons licence, unless indicated otherwise in a credit line to the material. If material is not included in the article's Creative Commons licence and your intended use is not permitted by statutory regulation or exceeds the permitted use, you will need to obtain permission directly from the copyright holder. To view a copy of this licence, visit http://creativecommons.org/licenses/by/4.0/.

Publisher's Note Springer Nature remains neutral with regard to jurisdictional claims in published maps and institutional affiliations.

Auroral Physics

Edited by David Knudsen, Joe Borovsky, Tomas Karlsson, Ryuho Kataoka and Noora Partmies

The original article can be found online at https://doi.org/10.1007/s11214-021-00796-w

Extended author information available on the last page of the article 


\section{Authors and Affiliations}

\section{Ryuho Kataoka ${ }^{1,2}$ (D) Christopher C. Chaston ${ }^{3}$. David Knudsen ${ }^{4} \cdot$ Kristina A. Lynch ${ }^{5}$. Robert L. Lysak ${ }^{6}$. Yan Song ${ }^{6} \cdot$ Robert Rankin $^{7} \cdot$ Kiyoka Murase $^{2} \cdot$ Takeshi Sakanoi $^{8}$. Joshua Semeter ${ }^{9} \cdot$ Tomo-Hiko Watanabe $^{10} \cdot$ Daniel Whiter $^{7}$}

R. Kataoka

kataoka.ryuho@nipr.ac.jp

C.C. Chaston

ccc@ssl.berkeley.edu

D. Knudsen

knudsen@ucalgary.ca

K.A. Lynch

kristina.a.lynch@dartmouth.edu

R.L. Lysak

lysak001@umn.edu

Y. Song

yan@umn.edu

R. Rankin

rrankin@ualberta.ca

K. Murase

murase.kiyoka@nipr.ac.jp

T. Sakanoi

tsakanoi@pparc.geophys.tohoku.ac.jp

J. Semeter

jls@bu.edu

T.-H. Watanabe

watanabe.tomohiko@nagoya-u.jp

D. Whiter

d.whiter@soton.ac.uk

1 National Institute of Polar Research, 10-3 Midori-cho, Tachikawa, Tokyo 185-0031, Japan

2 SOKENDAI, 10-3 Midori-cho, Tachikawa, Tokyo 185-0031, Japan

3 Space Sciences Laboratory, University of California, Berkeley, CA 94720, USA

4 Dept of Physics and Astronomy, University of Calgary, Calgary, AB T2N 1N4 Canada

5 Dept of Physics and Astronomy, Dartmouth College, Hanover, NH 03755 USA

6 School of Physics and Astronomy, University of Minnesota, Minneapolis, MN, USA

7 Physics \& Astronomy, University of Southampton, SO17 1BJ, Southampton, UK

8 Planetary Plasma and Atmospheric Research Center, Aramaki-aza-Aoba 6-3, Aoba, Sendai, Miyagi 980-8578, Japan

9 Department of Electrical and Computer Engineering and Center for Space Physics, Boston University, Boston, MA, USA

10 Department of Physics, Nagoya University, Nagoya 464-8602, Japan 